How to cite this work: Gómez Gutiérrez, Á., Schnabel, S., Lavado Contador, F., de Sanjosé, J. J., Atkinson, A. D. J., Pulido Fernández, M., \& Sánchez Fernández, M. (2018). Studying the influence of livestock pressure on gully erosion in rangelands of SW Spain by means of the UAV+SfM workflow. Boletín de la Asociación de Geógrafos Españoles, 78, 66-88. doi: http://dx.doi.org/10.21138/bage.2712

\title{
Studying the influence of livestock pressure on gully erosion in rangelands of SW Spain by means of the UAV+SFM workflow
}

Analizando la influencia del pastoreo en la erosión por cárcavas de las dehesas del suroeste español mediante el empleo de UAV+SfM

\author{
Álvaro Gómez Gutiérrez \\ alvgo@unex.es \\ Susanne Schnabel \\ schnabel@unex.es \\ Francisco Lavado Contador \\ frlavado@unex.es \\ Geoenvironmental Research Group \\ University of Extremadura (Spain) \\ José Juan de Sanjosé \\ j̈blasco@unex.es \\ Alan D. J. Atkinson \\ atkinson@unex.es \\ NEXUS Research Group \\ University of Extremadura (Spain)
}




\title{
Manuel Pulido Fernández
}

\author{
mapulidof@unex.es \\ Geoenvironmental Research Group \\ University of Extremadura (Spain)
}

\section{Manuel Sánchez Fernández}

\author{
msf@unex.es \\ NEXUS Research Group \\ University of Extremadura (Spain)
}

\begin{abstract}
Gully erosion in agrosilvopastoral systems of SW Spain represents a common degradation process, but has been hardly analysed. The suitability of using the Unmanned Aerial Vehicles (UAV) and Structure from Motion photogrammetry (SfM) workflow to map small valley-bottom gullies in these landscapes was tested. The results showed centimetre-level accuracy. Observed strengths and limitations of the UAV+SFM workflow in the study areas are discussed. The resulting cartography allowed mapping soil erosion forms at outstanding spatial scales. All study areas showed evidences of degradation.
\end{abstract}

Key words: UAV+SFM; gully erosion; headcuts; valley bottoms; overgrazing.

\section{Resumen}

La erosión por cárcavas supone un proceso de degradación del suelo frecuente en los sistemas agrosilvopastoriles del SO español que ha sido poco estudiado. Se analizan aquí la viabilidad de uso de vehículos aéreos no tripulados (UAV) y la fotogrametría SfM para cartografiar cárcavas de fondo de valle en estos paisajes. Los resultados muestran precisión centimétrica. Se debaten las fortalezas y limitaciones de la metodología empleada. La cartografía resultante permitió cartografiar las formas erosivas a una escala excepcional. Todas las zonas de estudio mostraron evidencias de degradación.

Palabras clave: UAV+SfM; erosión por cárcavas; cabeceras; fondos de valle; sobrepastoreo.

\section{Introduction}

Dehesas are complex agro-silvo-pastoral systems that extends over approximately 4 million of hectares in the S and SW of the Iberian Peninsula. There, previous studies have shown physical soil degradation as one of the most important environmental problems (Schnabel, 1997) that includes 
sheet erosion in hillslopes and gully erosion in valley bottoms. The magnitude of these processes is highly related to human pressure (Schnabel, 1997; Gómez Gutiérrez et al., 2009) together with environmental characteristics (i.e. lithology, topography, soils and climate).

Gully erosion is an important phenomenon in the valley bottoms of first and second order catchments of dehesas. The presence of gullies in these valley bottoms produces degradation due to soil loss but also favours drainage enhancing runoff. At landscape scale, gullied channels constitute effective links that transfer runoff and sediments and increase landscape connectivity (Poesen et al. 2003). The availability of water represents an important concern due to the climatic characteristics of the Iberian Peninsula and the global warming scenario.

Previous work by Gómez Gutiérrez et al. (2009) pointed out land use intensity as the main factor determining incision episodes in valley-bottom gullies of dehesas at medium-term temporal scale. However, this and other works have been limited because of the detailed spatial scale required to map, quantify and understand soil erosion processes in small gullies.

The most common methods traditionally used to register gully topography are pin networks (Chaplot, 2013), poles, topographic profilers (Casalí et al., 2006), total stations (Ehiorobo \& Audu, 2012), Light Detection and Ranging sensors (LIDAR; Evans \& Lindsay, 2010), Terrestrial Laser Scanners (TLS; Perroy et al., 2010), aerial photographs and traditional photogrammetry (Ries \& Marzolff, 2003), Terrestrial SfM (Castillo et al., 2012) and Global Navigation Satellite Systems (GNSS; Hu et al., 2009).

In the past decade, we have attended to a proliferation in the use of Unmanned Aerial Vehicles (UAVs) in the field of Earth Sciences because of the advantages of these devices over more traditional monitoring and remote sensing methods. UAVs can provide high temporal and spatial resolutions at reasonable costs of money and time. In Geosciences, UAVs can reach remote or dangerous places and can provide images acquired from viewpoints impossible for hand-held sensors and without altering the topographic surface. The utility of UAVs has been strengthened by the concurrent spread of automatic photogrammetry techniques known as Structure from Motion (SFM) and the improvement in the navigation systems used by these vehicles. Based on these advantages, some authors have attributed to this technology the potential to change the Earth sciences' methods in a similar way that Geographical Information Systems (GIS) and GNSS did in the past (Watts et al., 2012). In the field of Geomorphology, recent examples about the ensemble of UAV+SfM are: Niethammer et al. (2017), Hugenholtz et al. (2013), Lucieer et al. (2014), Turner et al. (Turner et al. 2015), Fernández et al. (2016), Neugirg et al. (2016), Westoby et al. (2016) and Cook (2017).

In the specific subject of gully erosion previous examples on the concurrent use of UAV+SfM are scarce. Exceptions are Kaiser et al. (2014) who reconstructed a small gully in Morocco estimating 
the volume of soil eroded and Christian and Davis (2016) who modelled the topography of a hillslope gully in California. Despite these antecedents, the use of this unprecedented high-resolution 3D data to solve geomorphological problems is limited, as the scientific community has been focused on validating these techniques. In this paper we show how remote sensing new technologies can be applied to produce detailed maps (orthophotographs, DEMs and point clouds) of valley-bottom gullies and provide advice for better management strategies in dehesa farms. We focus on the use of fixed-wing UAVs that, theoretically, allow covering large surfaces with great detail. The main objectives of this work are:

1) testing the application of the UAV+SfM workflow to map valley-bottom gullies using a fixed-wing UAV and covering relatively large surfaces (study areas $\approx 0.31 \mathrm{~km}^{2}$ ),

2) characterizing processes and identifying, if possible, causes of gully erosion in a silvopastoral system and

3) recommend management strategies based on (1) and (2).

Therefore, this paper is oriented as using UAV+SFM in an applied research.

\section{Study area}

The study is carried out in five gully reaches located in three privately owned farms that are representative of the dehesa land use and exploitations systems (Buitrera, Parapuños and Raposera: Figure 1). The five selected reaches are located in valley bottoms formed by alluvial sediments covering the bedrock of Precambrian shales. These channels are typical of low order catchments in the SW Iberian Peninsula and present ephemeral discharges. They can present gentle banks and vegetation or they can be degraded with vertical walls, headcuts and other evidences of soil loss and can hence be classified as valley bottom gullies. Three reaches are located in the same farm named Raposera while the other two reaches are located in Buitrera and Parapuños farms.

The reach selected in Buitrera drains a catchment of 71 ha at the outlet (i.e. the most downstream point of the reach). This reach flows following S-SE direction and is part of a system of short tributaries of the Almonte River on its right bank. The selected reach is part of a discontinuous gully and presents a length of $746 \mathrm{~m}$. The topography is undulated with average slope gradients of $10 \%$ and $2 \%$ for hillslopes and valley bottoms respectively. Average annual rainfall amounts to $646 \mathrm{~mm}$ and average annual temperature is $16^{\circ} \mathrm{C}$.

Parapuños farm is drained by discontinuous channels that are tributaries of the Almonte River on its right bank. The selected reach is a first order channel with a total length of $792 \mathrm{~m}$ and is part of the gully previously studied by Gómez-Gutiérrez et al. (2009, 2012, 2014). The estimated drainage area at the outlet of the selected reach is 49 ha. The average slope amounts to $7 \%$ with maximum 
values of $12 \%$ in the hillslopes. The average annual rainfall is $525 \mathrm{~mm}$ with a standard deviation of $167 \mathrm{~mm}$

Figure 1. (a) Geographical setting and (b) location of the study areas

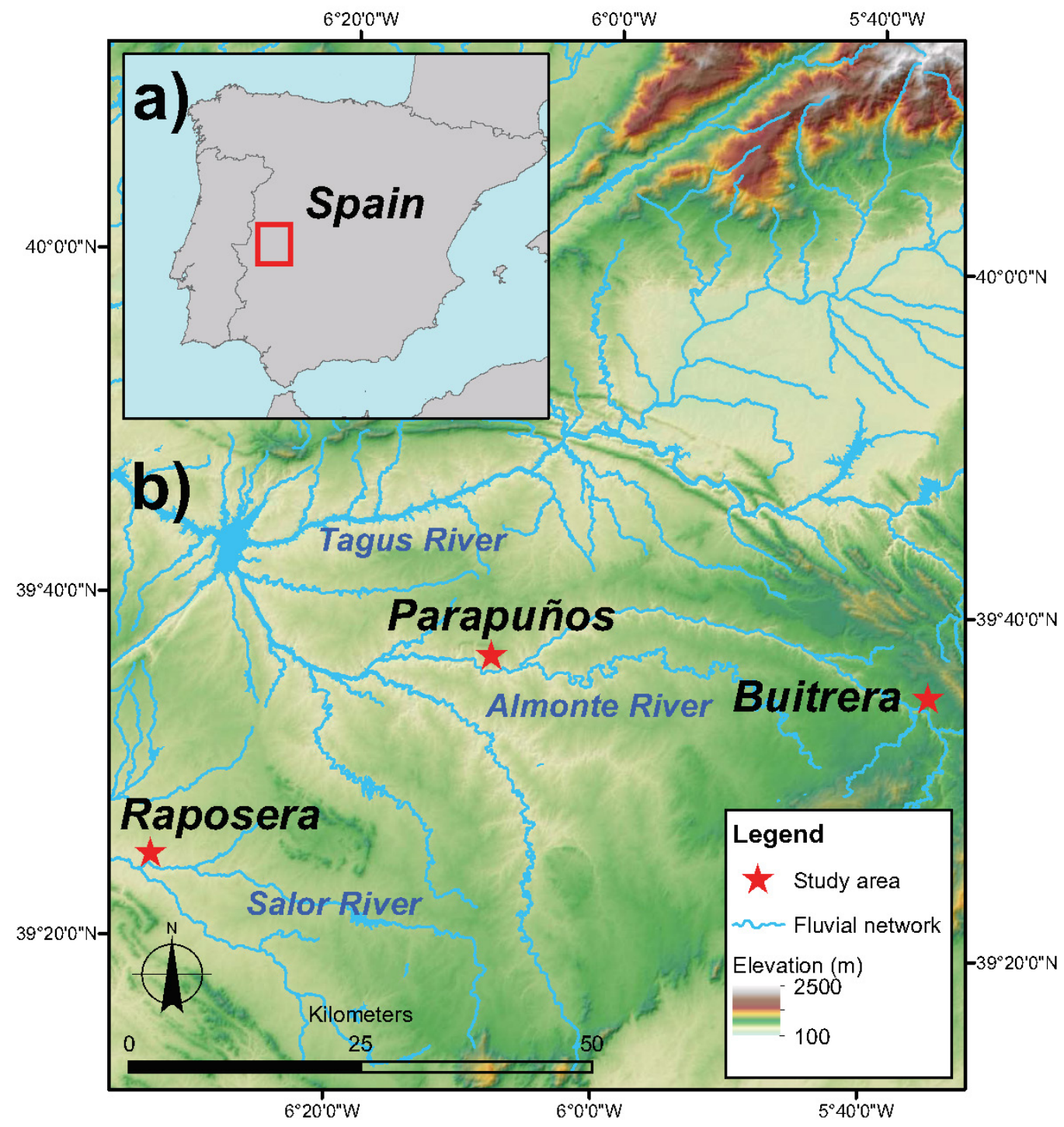

Source: own elaboration

Raposera stream flows into the Salor River with a drainage area of 232 ha. Three reaches flowing in three different valleys of the catchment were selected (R1, R2 and R3). They represent different stages of gully development. R1 reach is the western one and shows the most advanced stage of development with a continuous channel and a drainage area of 336.9 ha. R2 is located between R1 and R3 and has a drainage area of 7.4 ha. R3 is the eastern one and drains an area of 76.2 ha. Average annual rainfall amounts to $518 \mathrm{~mm}$ with a standard deviation of $158 \mathrm{~mm}$. 


\section{Material and methods}

The study areas were surveyed using a fixed-wing UAV Ebee carrying on-board a Sony WX220 camera that was used to capture high-resolution aerial photographs. Three flights were carried out as the three reaches in Raposera were surveyed during the same mission. The flight track and the capture of the photographs were pre-programmed using the software eMotion2. Flight plan parameters were set to ensure the highest resolution and accuracy in the resulting cartographic products (Table 1). For example, Ground Sampling Distance (GSD) was set to the minimum value of $1.4 \mathrm{~cm}$ while lateral and longitudinal overlaps were pre-defined to 75 and $85 \%$. Only take-off and landing parameters were set during the field survey depending on weather conditions. The Ebee incorporates a GPS receiver on-board with a global estimated accuracy of 3-5 $\mathrm{m}$. Therefore, artificial Ground Control Points (GCPs) measured by means of a DGPS device are necessary to get an accuracy enough. CGPs were acquired during each field survey using a Leica GPS 1200 System (with RTK y Post-Processed solutions using GPS+GLONNASS satellites). The final accuracy of the CGP was $<2.5 \mathrm{~cm}$. After the flight, the eMotion2 software was used to download the photographs and the coordinates of the path followed by the UAV. This information was used as input in Pix4D software, which was utilized for the photo-reconstruction procedure. Pix4D uses SFM and MVS algorithms to produce a dense point cloud from pictures and allow using GCPs to optimize camera calibration parameters. Additionally to the point cloud, Pix4D produces orthomosaics, 3D triangular texturized mesh models, Digital Surface Models (DSMs) and Digital Elevation Models (DEMs). During this procedure, GCPs are used to scale and georeference the 3D model after an initial processing but before the bundle adjustment in order to minimize systematic errors (James and Robson 2014). Again, all the processing options were set to get the most accurate cartographic products (Table 1). Characteristics of the computer hardware utilized to process the datasets are presented in Table 1. Recently, James et al. (2017) highlighted the importance of publishing flight parameters and processing options in geomorphological research to improve our understanding of their relationships with error estimations.

Table 1. Flight plan parameters, processing options and hardware used

\begin{tabular}{|l|l|}
\hline \multicolumn{2}{|l|}{ Flight plan options (eMotion2 software) } \\
\hline Ground Resolution (cm) & 1.4 \\
\hline Approximate flight altitude (m) & 49.4 \\
\hline Mission area & Polygonal \\
\hline Overlap, lateral and logitudinal (\%) & $75-85$ \\
\hline Distance between photos & Automatic \\
\hline Perpendicular flight lines & No \\
\hline Pitch angle $\left({ }^{0}\right)$ & 7 \\
\hline Landing & Lineal \\
\hline
\end{tabular}

Table 1. Continues 


\begin{tabular}{|l|l|}
\hline Processing options (Pix4D software) \\
\hline Image scale & Multiscale, 1 \\
\hline Calibration & Automatic \\
\hline Calibration method & Standard \\
\hline $\begin{array}{l}\text { Optimizing internal-external camera } \\
\text { parameters }\end{array}$ & All \\
\hline Point density & High \\
\hline Minimum matches & 3 \\
\hline $\begin{array}{l}\text { Limiting camera depth } \\
\text { automaticallly }\end{array}$ & No \\
\hline Coordinate system & WGS84 UTM 29 and 30 \\
\hline Computer hardware & Intel Core i7-4710HQ 2.5 \\
\hline CPU & GHz \\
\hline RAM & 7 GB \\
\hline GPU & Intel HD Graphics 4600 \\
\hline
\end{tabular}

Source: own elaboration

Two different software packages were used for the analysis and management of the point clouds, the 3D mesh, the DSMs and the DEMs: Cloudcompare for the point clouds and ArcGIS and SAGA for the DSMs, the DEMs and the orthophotographs. The channels (thalweg and banks), headcuts, streambank access paths, recent deposits and collapsed materials were digitized. To support the mapping procedure, 3 and 2.5 dimensional visualizations were prepared in CloudCompare and ArcGIS respectively. For each study site, an area of analysis defined by a buffer of $5 \mathrm{~m}$ from de thalweg of every mapped channel was defined. Previous works have used a similar approach to analyze the influence of livestock in the riverbanks of gullies (Zaimes \& Schultz, 2012) or streams (Belsky et al., 1999). Generally, channel morphology and vegetation cover can be used to differentiate between degraded and non-degraded reaches. Additionally, the presence of gully headcuts and vertical walls works as an indicator of channel erosional activity. A reach was considered degraded when the banks were bare of vegetation or/and slopes $>45^{\circ}$. This condition includes the three classical cross-sections of gullies, the U-shaped, the $V$-shaped and the trapezoidal. Finally, data about livestock type and density were obtained by interviews with owners (PulidoFernández et al., 2013).

\section{Results and discussion}

\subsection{Characteristics of the resulting cartography}

Table 2 presents the main characteristics of each dataset and field survey. The field surveys were carried out from March to July in 2016 and the flights covered areas that varied from $0.31 \mathrm{~km}^{2}$ to $0.37 \mathrm{~km}^{2}$. The resulting GSD varied from $1.63 \mathrm{~cm}$ to $3.83 \mathrm{~cm}$ while the Mean Absolute Errors (MAEs) and the RMSEs were, in the three cases, $<2 \mathrm{~cm}$. The figures of the MAE and/or RMSE $(<2 \mathrm{~cm})$ and the survey range (i.e. average flight height $\approx 49.4 \mathrm{~m}$ ) agree with the validations of SFM 
compiled by Smith and Vericat (2015). Although the ratio RMSE:survey range obtained here $(1: 2,470)$ improved the total average (1:639) presented by Smith and Vericat (2015) and the one estimated by James y Robson $(1: 1,000 ; 2012)$. Numerous factors are involved and support these differences: UAV, camera, quality and distribution of GCPs, geometry of the pose, number of images, weather, terrain complexity, software and workflow. The characteristics of the datasets regarding spatial resolution and accuracy improve the performance of satellite optical images available until now (Wang et al. 2016). At the same time the fixed wing UAV allowed covering relatively large study areas $\left(>0.30 \mathrm{~km}^{2}\right)$.

Table 2. Characteristics of the flights and models. GSD= ground sampling distance, $\mathrm{GCP}=$ ground control point, $\mathrm{MAE}=$ mean absolute error and $\mathrm{RMSE}=$ root mean square error

\begin{tabular}{|l|c|c|c|}
\cline { 2 - 4 } \multicolumn{1}{c|}{} & Buitrera & Parapuños & Raposera \\
\hline Flight date & $01 / 04 / 2016$ & $25 / 01 / 2016$ & $21 / 07 / 2016$ \\
\hline Area covered $\left(\mathrm{km}^{2}\right)$ & 0.3681 & 0.3072 & 0.3628 \\
\hline Final GSD $(\mathrm{cm})$ & 3.83 & 1.85 & 1.63 \\
\hline Captured images $(\mathrm{n})$ & 279 & 276 & 295 \\
\hline Calibrated images (n) & 279 & 274 & 290 \\
\hline $\begin{array}{l}\text { Mean reprojection error } \\
\text { (pixels) }\end{array}$ & 0.20 & 0.18 & 0.21 \\
\hline GCP $(\mathrm{n})$ & 10 & 10 & 10 \\
\hline MAE (m) & 0.014 & 0.013 & 0.012 \\
\hline RMSE (m) & 0.018 & 0.016 & 0.016 \\
\hline $\begin{array}{l}\text { Median volumetric point } \\
\text { density (ptos·m }\end{array}$ & 382 & 251 & 235 \\
\hline $\begin{array}{l}\text { Required automatic } \\
\text { processing time (h:mm) }\end{array}$ & $5: 50$ & $5: 15$ & $5: 30$ \\
\hline
\end{tabular}

Source: own elaboration

The GSD of the resulting orthomosaics and models as well as the volumetric point density of the point clouds (Table 2 and Figure 2) allowed a detailed interpretation of the landforms in every reach and its surrounding area. GSD and point density are key parameters for the accuracy of the resulting models (Mosbrucker et al. 2017). Particularly useful were the orthomosaics as they provided continuous information of the elements in the landscape in those areas where the 3D information of the point cloud was missed. The lack of information in some parts of the point clouds was due, mainly, to the difficulties of the SFM software to reconstruct the homogeneous texture of some features in the landscape, particularly specific vegetation plant species, and the line-of-sight effect. Problems reconstructing vegetation features using SFM have been reported in the literature (Westoby et al., 2012; Gómez-Gutiérrez et al., 2014). Here, the crown of most of the trees and large shrubs were reconstructed (Figure 2b). However, areas with broom shrubs (Retama sphaerocarpa L.) 
produced no-data zones in the point cloud. This kind of shrub is particularly challenging for lowaltitude SFM as they are usually large but with very thick leaves and branches that move easily by gentle breezes and result in homogeneous textures. This problem was only observed in Parapuños as Retama sphaerocarpa L. was not present in Buitrera or Raposera.

Figure 2. Histogram (a) and spatial distribution of the volumetric point density

(b) for a detailed portion of the point cloud for parapuños showing a small reach of the channel with a nearby tree. Histogram of the volumetric point density (c), point cloud with RGB

(d) and spatial distribution of the volumetric point density

(e) for a detailed portion of raposera point cloud showing two small parallel headcuts

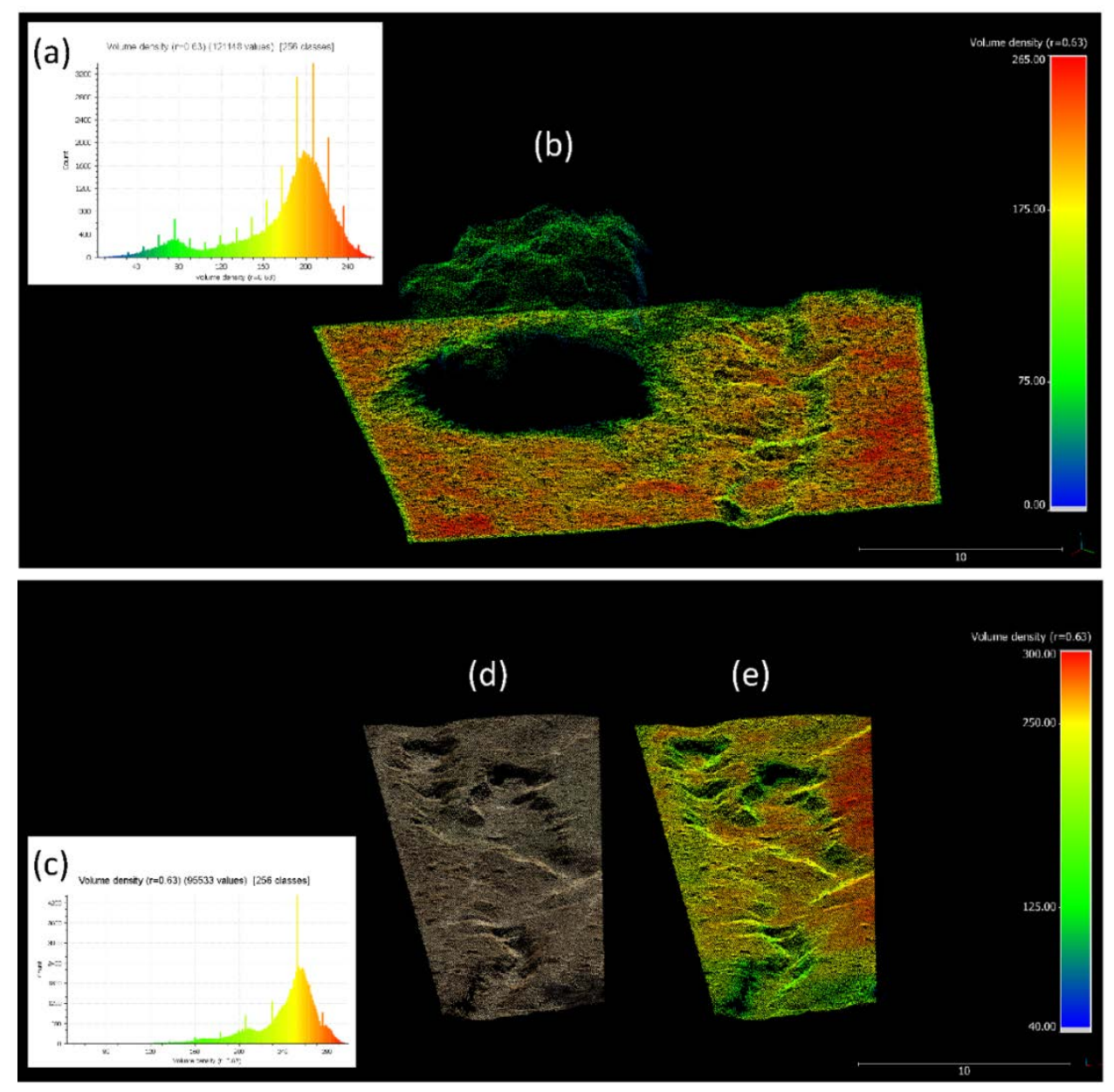

Source: own elaboration

As stated before, the crown of trees and large shrubs were reconstructed correctly (Figure 2b); however, these vegetation features resulted in absence of points in the cloud below their canopies (Figure 2b). This is particularly important in landscapes like dehesa with disperse tree cover because resulting DEMs probably will present circle-like artefacts in those areas covered by trees. In these landscapes, the point clouds produced by UAV+SFM workflow should be carefully post-processed in order to get reliable DEMs that could be useful for geomorphologists. Integration of topographical 
information from different sources (e.g. TLS or LIDAR) could minimize these problems. In our study case, the presence of trees just above the channels was incidental. Figure 3 presents details of the cartographic products obtained. Figures $3 d$ and $3 e$ present hillshades of the DSM and DEM respectively, showing the good performance of the algorithm implemented in Pix $4 D$ to suppress trees from the DSM.

Figure 3. (a) Orthophotograph of $r 3$ showing several headcuts and a detail of one of them showing collapsed material, (b) the same area after mapping geomorphic units, headcuts, banks and animal paths, (c) orthophotograph of buitrera,

(d) hillshade of the DSM generated for the same area, (e) hillshade of the digital elevation model for the same area and $(f)$ map produced for the same area

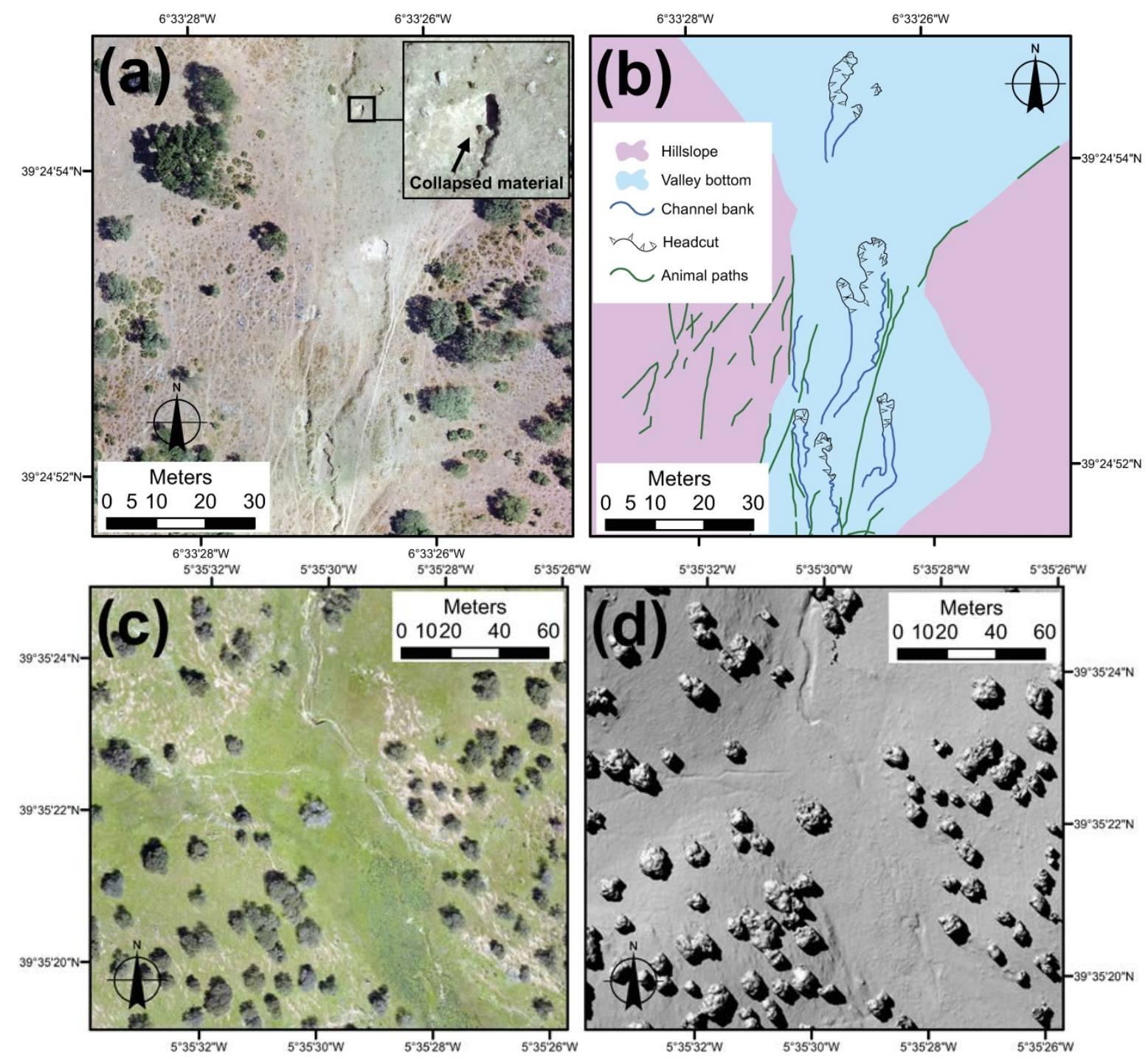


Figure 3. Continues

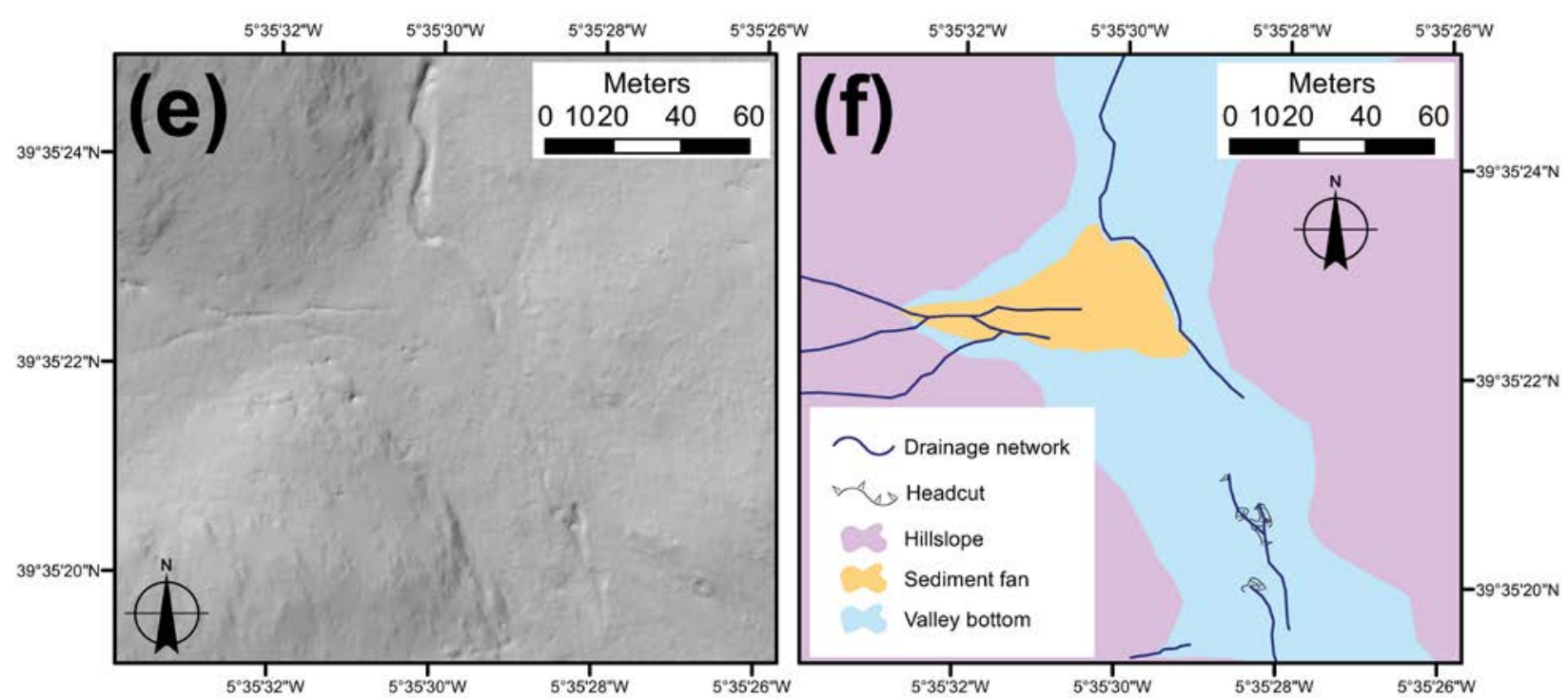

Source: own elaboration

The line-of-sight effect was responsible of low volumetric point densities in certain vertical banks and gully walls (Figure 2c, $d$ and e) even in the case that lateral and longitudinal overlaps in the flight plan were set to $75 \%$ and $85 \%$ respectively. In Figure $2 \mathrm{~d}$ a portion of a point cloud representing two parallel small headcuts is shown. Figure $2 e$ represents the spatial distribution of volumetric point densities for that area. Vertical walls in the banks present values $\approx 125$ points $\bullet \mathrm{m}^{-3}$ while the base of the scarp of both headcuts showed no data regions. The absence of points in these undercut walls is critical from a geomorphological viewpoint as these are the most dynamic areas but its influence on the estimations of the eroded soil volume is minimal (Frankl et al., 2015). When a more detailed representation of these headcuts or undercutting walls is necessary, terrestrial SfM (Gómez-Gutiérrez et al., 2014) or a detailed and lower flight with a quadcopter UAV could deliver better results though covering smaller surfaces. Smith and Vericat (2015) suggested that beyond plot sizes of 100 $\mathrm{m}^{2}$, aerial SFM is preferable to terrestrial SFM. Although they pointed out that for landscape-scale surveys, a large range is necessary for a manageable dataset. In the present study landscape-scale surveys (covering areas $>0.30 \mathrm{~km}^{2}$ ) were carried out using a range $\approx 50 \mathrm{~m}$ with a few hours of processing-time $(<6 \mathrm{~h})$ and obtaining $\mathrm{cm}$-level accuracies. Gullies modelled in the recent scientific literature using UAV+SFM (Kaiser et al., 2014; Christian \& Davis, 2016) presented larger crosssections but covered smaller surfaces $\left(<100 \mathrm{~m}^{2}\right)$. These studies used multicopters that allow hovering instead of the fixed-wing UAV used herein.

A classical problem with fixed-wing UAV and SFM approaches is the possibility of transferring systematic dome-type errors to the cartographic products (James \& Robson, 2014). This possibility is minimized here with: 1) a proper distribution of GCPs over the study area, 2) using the GCPs in the 
bundle adjustment, 3) using a pitch angle of $7^{\circ}$ and alternating the direction of flight lines and 4) using accurate specific camera model included in Pix4D.

\subsection{Characterization of gullies and forms and interpretation of processes}

Digitized channels presented a total length of 2,685 $\mathrm{m}$ and covered an area of 8,698 $\mathrm{m}^{2}$, from which $90.6 \%$ was considered degraded (i.e. gullied reaches). Evidences of gully erosion were found in every study area with percentages of gullied reaches that varied from $55.16 \%$ to $100.00 \%$ in R2 and Parapuños respectively (Table 3). Vertical or undercutting walls, headcuts, bank headcuts, banks uncovered by vegetation and collapsed materials were found in different frequencies in the study areas (Table 3). Figure 3 presents examples of these features, showing that small headcuts and even small blocks of collapsed material could be identified (Figure 3a).

The visualization of the obtained 3D models (Figure 4), in addition to the more classical visualization of $2.5 \mathrm{D}$ models (Figure 3d), allowed an augmented insight of gully features. Illustrations, as Figure 4, present an incredible value for geomorphologist and probably, would be the basis of geomorphological mapping in the upcoming years. Even with these tools, the interpretation of erosive channel forms and processes in Buitrera is not straightforward. Most of the channel was covered by a layer of herbaceous vegetation indicating low erosional activity and the predominance of depositional processes with reaches showing flat or convex channel beds. Even vertical banks were covered by vegetation but their existence beside headcuts indicates a previous cycle of incision. The dominance of depositional processes in the channel indicates that the catchment is producing an amount of sediments (by sheetwash erosion of hillslopes) that cannot be evacuated by the concentrated flow, thereby filling the channel. Evidences of both processes are clearly visible in Figure $3 c$ with bare soils in the hillslope and vegetation and valley bottoms covered by a dense layer of herbaceous vegetation. Figure 5a shows the relationship between the channel reach area and the number of headcuts mapped for the five study areas. Buitrera showed only 11 headcuts for a channel reach mapped area of 3,465 $\mathrm{m}^{2}$ and was an outlier in the relationship between headcut number and channel reach area. Excluding Buitrera improved the relationship substantially ( $n=4$, $r^{2}=0.99$ and $p=0.01$; Figure 5a). Filling cycles or the alternation of infilling and incision episodes in gullies have been previously reported in the literature and attributed to external forces (e.g. overgrazing: Zucca et al., 2006) or intrinsic factors (e.g.: Humphrey \& Heller, 1995).

In the southern part of the reach an ephemeral small stream tributary on the right bank joins the gully forming a sediment fan that has modified the course of the channel (Figure 3d-e). This fan, as well as previous studies (Rubio-Delgado et al., 2014) confirm the important supply of material from the hillslopes. Downstream the sedimentary fan the channel becomes discontinuous and 7 headcuts are located in a part of the valley bottom which is saturated of water during the rainy season (most frequently from November to February). The hypothesis herein is that saturation of the valley bottom 
by water reduces the cohesion of the gully banks with a more ductile behaviour of soils. Similar findings were observed by Gómez-Gutiérrez et al. (2012) and Thomas et al. (2004).

Table 3. Digitized features and data about livestock

\begin{tabular}{|c|c|c|c|c|c|}
\hline & Buitrera & Parapuños & Raposera 1 & Raposera 2 & Raposera 3 \\
\hline Date & $01 / 04 / 2016$ & $25 / 01 / 2016$ & $21 / 07 / 2016$ & $21 / 07 / 2016$ & $21 / 07 / 2016$ \\
\hline Headcuts (n) & 11 & 48 & 12 & 2 & 23 \\
\hline Bank headcuts (n) & 3 & 34 & 12 & 0 & 3 \\
\hline Access paths (n) & 20 & 100 & 39 & 11 & 37 \\
\hline Channels length (m) & 746.10 & 792.12 & 345.78 & 255.92 & $545.16^{*}$ \\
\hline Reach area $\left(\mathrm{m}^{2}\right)$ & 3,465 & 2,291 & 1,066 & 533 & 1,343 \\
\hline Reach gullied area $\left(\mathrm{m}^{2}\right)$ & 3,075 & 2,291 & 1,042 & 294 & 1,175 \\
\hline Reach gullied area (\%) & 88.7 & 100.0 & 97.7 & 55.2 & 87.5 \\
\hline Headcuts for reach length $\left(n \cdot \mathrm{km}^{-1}\right)$ & 14.74 & 60.60 & 34.70 & 7.81 & 42.19 \\
\hline $\begin{array}{l}\text { Bank headcuts for reach length } \\
\left(n \cdot \mathrm{km}^{-1}\right)\end{array}$ & 4.02 & 42.92 & 34.70 & 0.00 & 5.50 \\
\hline Paths for reach length $\left(\mathrm{n} \cdot \mathrm{km}^{-1}\right)$ & 26.81 & 126.24 & 112.79 & 42.98 & 67.87 \\
\hline Drainage area $\left(\mathrm{km}^{2}\right)$ & 0.71 & 0.491 & 0.762 & 0.044 & 0.487 \\
\hline Gully average depth*width (m) & $0.63 * 4.36$ & $0.43 * 1.93$ & $1.03 * 3.40$ & $0.55 * 2.75$ & $0.60 * 3.01$ \\
\hline Livestock density (AU ha ${ }^{-1}$ ) & 1.17 & 3.00 & $0.35^{* \star}$ & 0.35 & 0.35 \\
\hline Livestock & Sheep, goats & Sheep, pigs & Cows & Cows & Cows \\
\hline
\end{tabular}

Key: Note that digitized features were located in a buffer of $5 \mathrm{~m}$ from the thalweg of the channe while drainage area is referred to the outlet of the reach. $A U=$ animal unit ( $1 \mathrm{cow}=1 \mathrm{~A}$; a pig=0.37 A; 1 sheep or goat= $0.12 \mathrm{AU})$.

Source: own elaboration

Figure 4. Detail of the 3D texturized mesh model produced for Raposera 3 showing the discontinuous channel, vertical walls, headcuts and animal paths

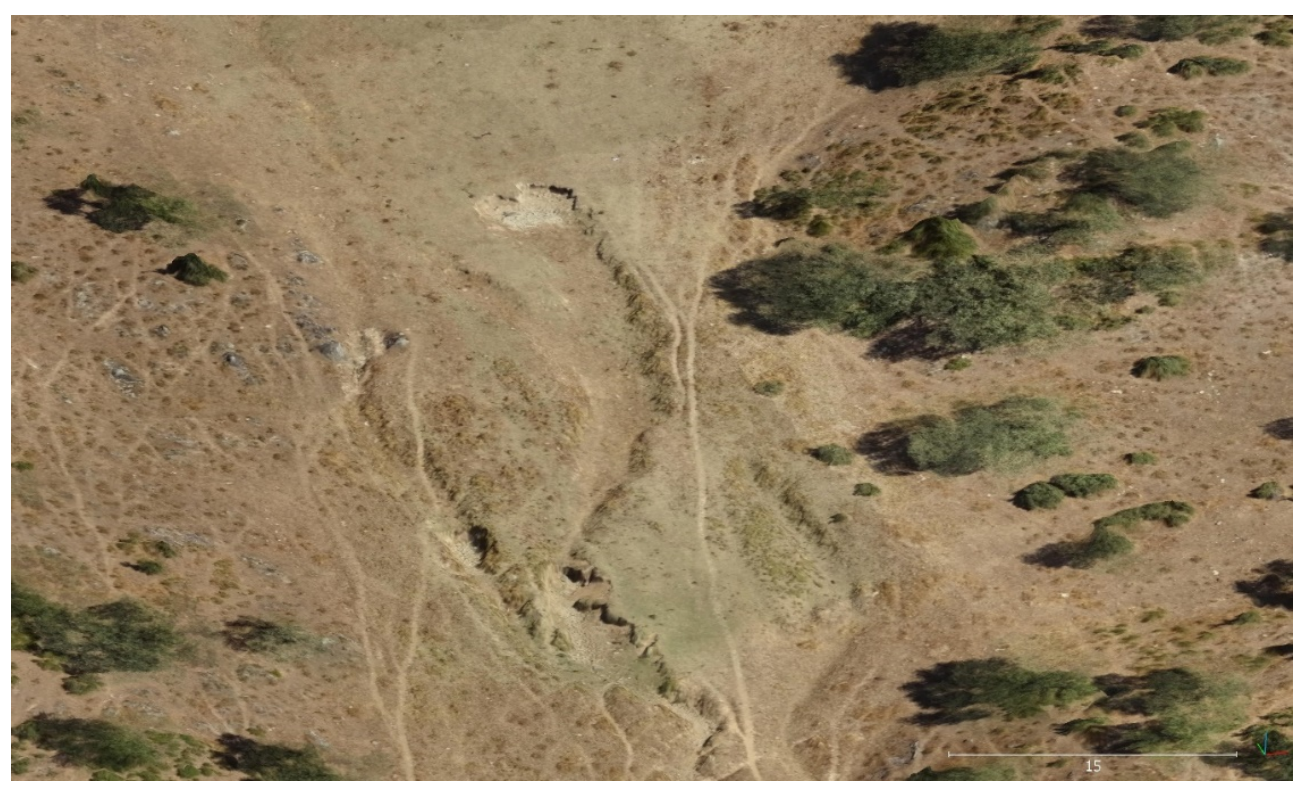

Source: own elaboration 
Figure 5. Relationship between (a) headcuts and channel reach area for the 5 study areas (regression line and equation in blue) and for the study areas excluding buitrera (regression line and equation in red) and (b) bank headcuts and access path
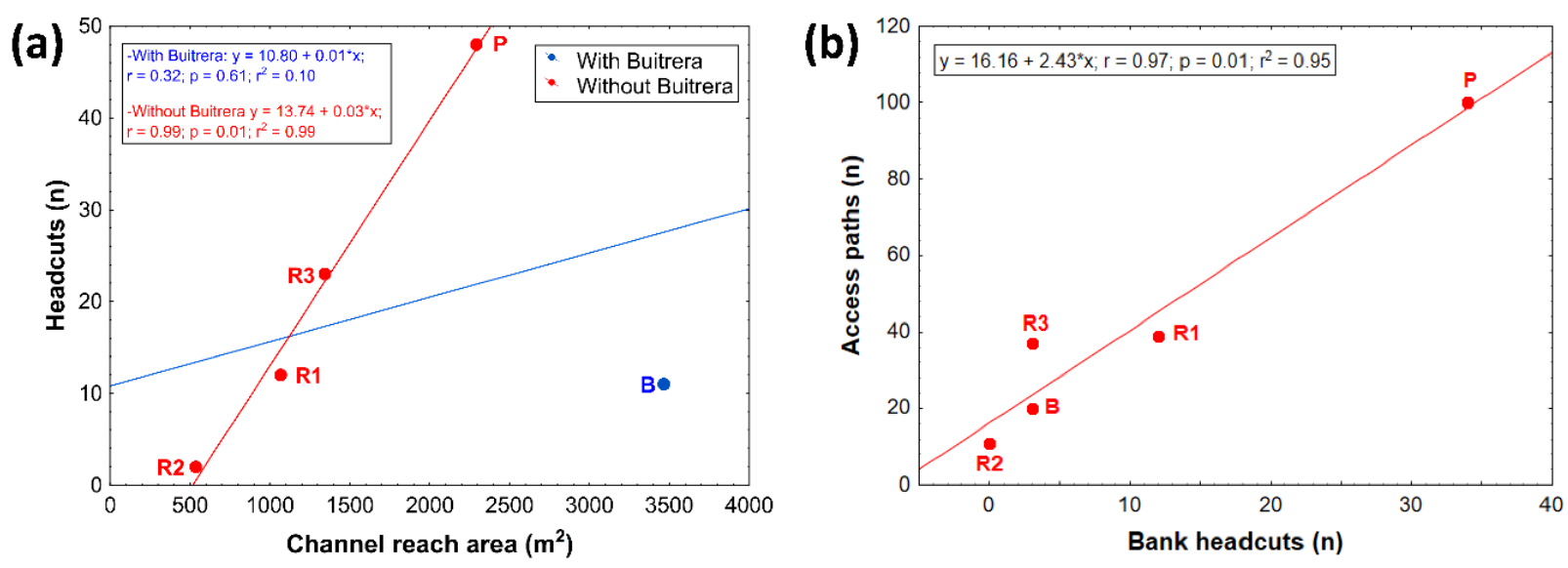

Key: B=buitrera, $P=$ parapuños and R1, R2 and R3=Raposera 1, 2 and 3

Source: own elaboration

Figure $5 b$ shows the relationship between the number of bank headcuts and the number of access paths. Access paths are the origin of bank headcuts, however they were not correlated to livestock density indicating that animal movements within every fence are playing an important role. In Parapuños, different processes and erosional features were identified in the gully and the surrounding area, but the more active areas are those located in the left bank and near sheep paths. In the last years, an important increase in lateral-bank headcuts has been observed (GómezGutiérrez et al., 2014). In these areas, animal paths perform like manifolds increasing connectivity and draining the water coming from the hillslope to the channel and producing these bank headcuts. The cattle streambank access paths to the gully are clearly visible in the orthophotographs (Figure 6a) and the DSM. Recently Tufekcioglu et al. (2013) highlighted the role of livestock streambank access paths producing and exporting most of the suspended sediments in streambank areas even when these paths represent a small portion of the streambank.

Two different animal paths were identified in Parapuños: small paths perpendicular to the channel (streambank access paths) and large paths parallel to the channel. The first ones are ramps that cattle use to enter and cross the gully while the second ones constitute the main itinerary of the flock. Both are playing important roles in the degradation of the valley bottom. Small perpendicular tracks favour the development of bank headcuts. When these headcuts retreat enough to reach the parallel main paths, the headcut is captured by the larger parallel tracks (Figure 6a) and a small channel, parallel to the main channel, is formed (Figure 6b). In some areas, these small channels have connected forming a new channel that drains the left bank and diverts the flow from the main channel. In fact, this diversion of flow from the main channel has promoted its recovery in terms of 
revegetation and sedimentation (Figure 6b). For example, profile 1 and 2 in Figure $6 b$ show different bed forms: while profile 1 shows a trapezoidal morphology result of sediment deposition, profile 2 shows a concave form indicating that incision has taken place recently. In order to corroborate the relationship between stream access paths and bank headcuts in Parapuños, the axis of each headcut was digitized along with the nearest animal path to each headcut. The azimuth of both vectors was estimated and related in Figure 7. These results showed that, as hypothesized, headcuts grow following small depressions caused by animals.

Raposera is of special interest because in these three valley bottoms some of the factors influencing gully erosion remain constant: climate, land use and vegetation cover. Therefore, size and characteristics of the drainage area are expected to be responsible of the differences between the three valley bottoms. R1 is a reach of a continuous and well-developed channel, R2 is an incipient channel and R3 is a discontinuous channel representing an intermediate stage between R1 and R2.

Two different headcut types were observed in Raposera: bank headcuts and headcuts following the flow direction. The first ones were mainly located in R1 as animals need to cross over the welldeveloped channel while the second ones represent the growth mechanism of the discontinuous channel (R3). They are located in saturation zones similar to headcuts in Buitrera hence their retreat mechanism is hypothesized to be the same. As deduced from the models produced here these headcuts represent the growing mechanism of a discontinuous channel (R3) to become a continuous gully (R1).

\subsection{Recommendations for land use and management}

Better pasture management strategies are necessary in the study areas, particularly those related with the animal transit within the valley bottoms. Fencing in and around existing gullies, forcing animals to cross the channel in specific areas and excluding the animals from the valley bottoms during the rainiest months can perform well in the cases of Parapuños and Raposera. Applying these measures could be challenging as the profitability of dehesa exploitations is, in general, very low, and an important reduction in the available workforce has been experienced in the last decades. The lack of shepherds was solved by fencing the farms and resulted, in many cases, in overgrazed and undergrazed areas, concentrating livestock pressure in valley bottoms. This polarization of farms has been related to other environmental problems such as the lack of tree recruitment (Herguido et al., 2017). Subsidizing technological instruments (e.g. temporary electric fence systems or UAVs) to guide the movement of animals in the valley bottoms in farms with gullying problems could help to reduce soil loss. In Buitrera, specific measures focused on minimizing sheetwash erosion are recommended. These measures include reducing livestock density in the affected hillslopes and revegetation with native herbaceous species. Assuming traditional seasonal grazing systems would be an interesting alternative to reduce livestock pressure but difficult to be applied. In any case, the 
spatial perspective in the management of the animals should be considered (Herguido et al., 2017) in order to reduce their presence in degraded or more vulnerable areas.

Figure 6. (a) Detail of the orthophotograph in parapuños showing bank headcuts perpendicular to the main channel and bank headcuts that have been captured by animal paths and (b) detail of an area where one captured headcut has retreated and formed a new channel parallel to the main one. The appareance of this channel diverts the flow from the main one promoting its recovery with deposition in the bed of profile 1 and incision in the bed of profile 2
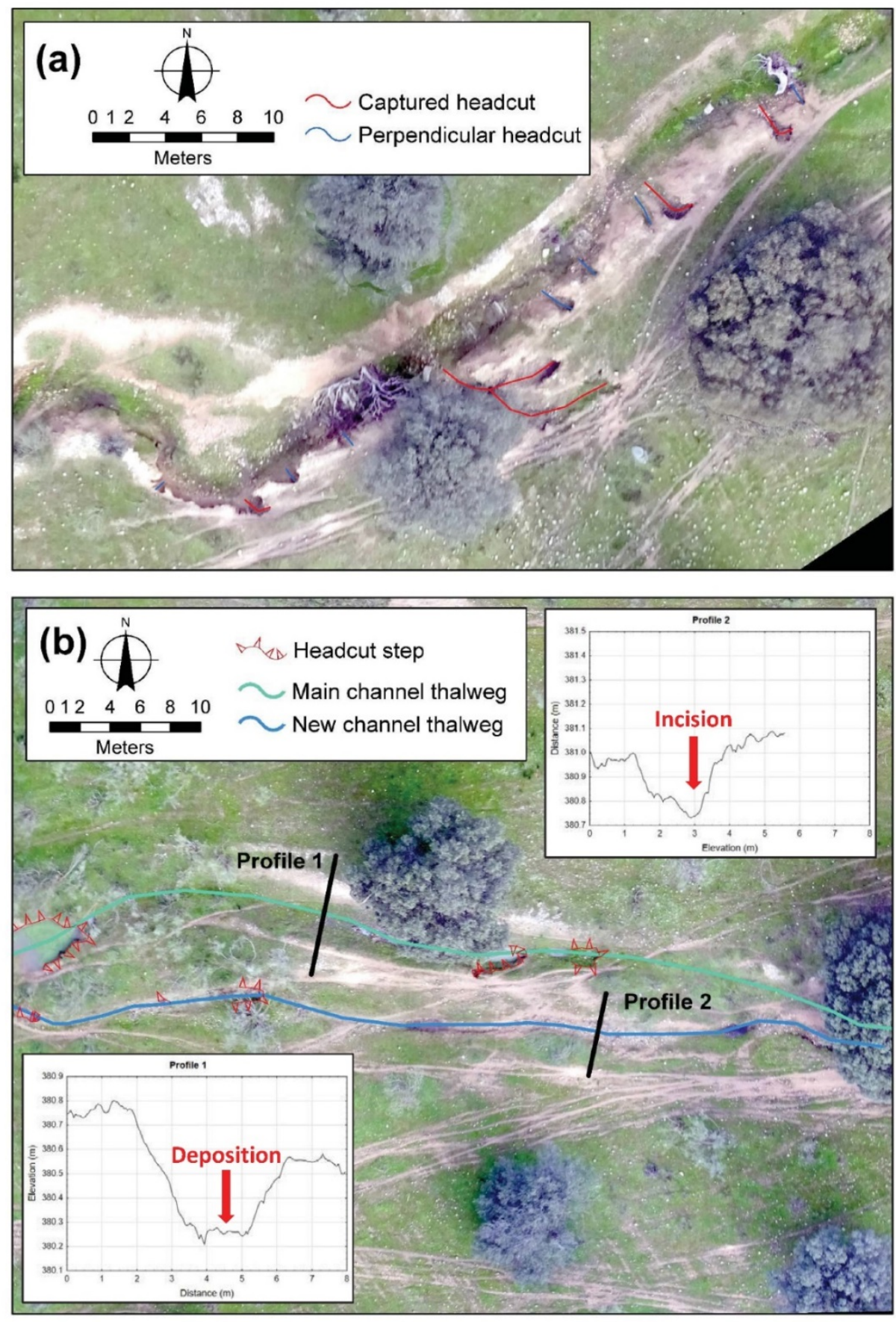

Source: own elaboration 
Figure 7. (a) vectors used for azimuth estimation of headcuts and animal paths,

(b) number of headcuts depending on their azimuth and (c) relationship between headcut azimuth and animal path azimuth
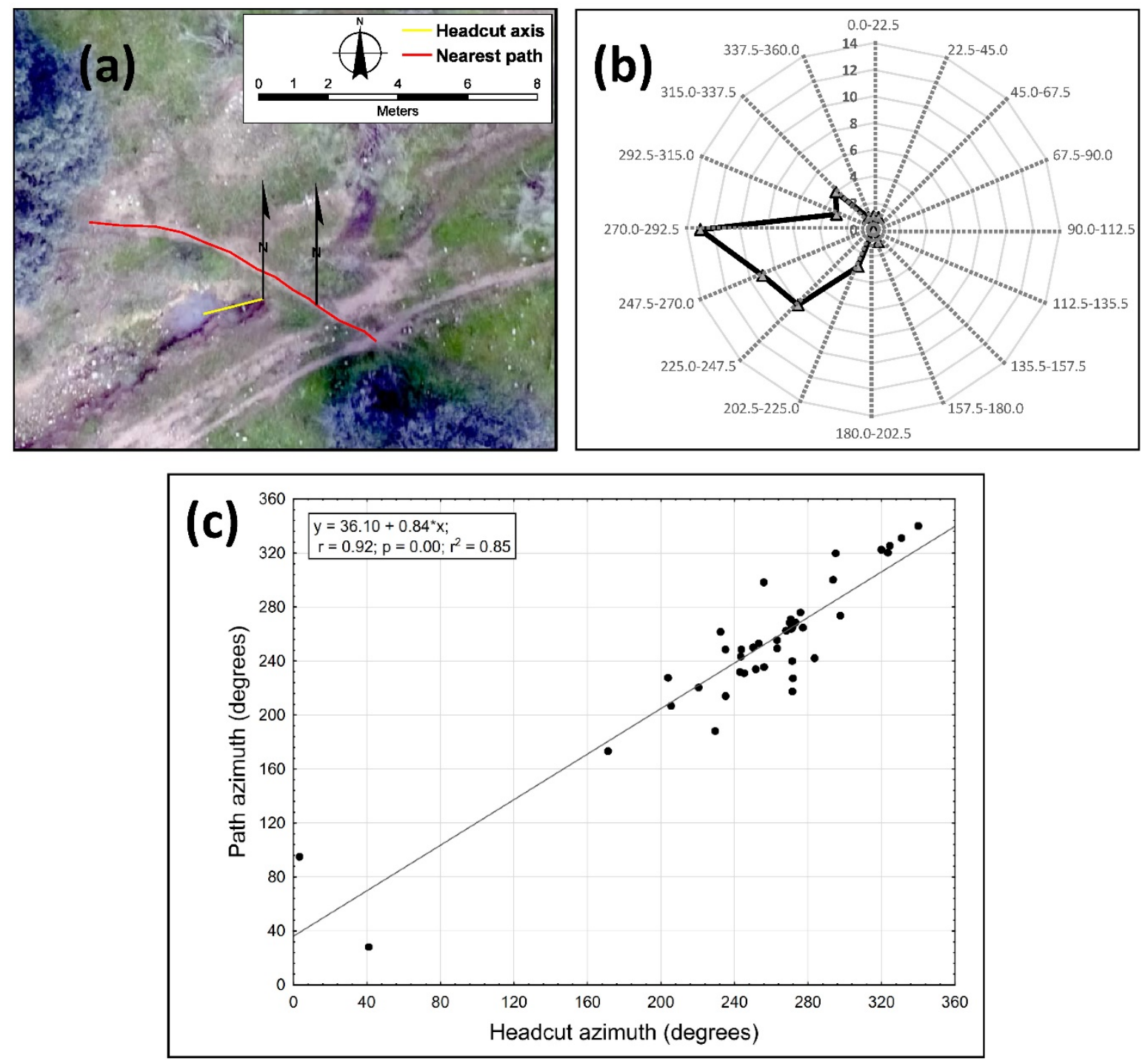

Source: own elaboration

\section{Conclusions}

The UAV+SfM workflow was applied to produce high-resolution 3D models for mapping erosion features inferring soil erosion processes at unprecedented spatial resolution for large surfaces in dehesa landscape.

Livestock grazing and movements promote bare soils, particularly the formation of tracks and small depressions that concentrate surface runoff leading to gully erosion in the valley bottoms. In some cases, they can vary the flow direction network forming alternative channels. Livestock streambank access paths provoke the creation of lateral-bank headcuts in the study area. Larger headcuts 
located in saturation zones are characteristics of discontinuous channels and their main growth mechanism.

Better pasture management strategies regarding the transit of animals in the valley bottoms are essential in dehesa landscapes.

Acknowledgments: This research was financed by the Spanish Ministry of Economy and Competitiveness (CGL2014-54822-R).

Authorship statement: The authors declare no conflict of interest. Álvaro Gómez-Gutiérrez, Susanne Schnabel, Francisco Lavado-Contador and Manuel Pulido-Fernández designed the research, performed data analysis and executed the manuscript writing. Álvaro Gómez-Gutiérrez and Francisco Lavado-Contador carried out flights, photogrammetric processing and mapping. José Juan de Sanjosé, Alan D.J. Atkinson and Manuel Sánchez-Fernández carried out field surveys and data analysis to support the geometrical accuracy and consistency of the cartographic products obtained. 


\section{References}

Belsky, A. J., Matzke, A., \& Uselman S. (1999). Survey of livestock influences on stream and riparian ecosystems in the western United States. Journal of Soil and Water Conservation, 54(1), $419-431$.

Casalí, J., Loizu, J., Campo, M. A., De Santisteban, L. M., \& Álvarez-Mozos, J. (2006). Accuracy of methods for field assessment of rill and ephemeral gully erosion. Catena, 67(2), 128-138. doi: http://dx.doi.org/10.1016/j.catena.2006.03.005

Castillo, C., Pérez, R., James, M. R., Quinton, N. J., Taguas, E. V., \& Gómez, A. (2012). Comparing the accuracy of several field methods for measuring gully erosion. Soil Science Society of America Journal, 76(4), 1319-1332. doi: http://dx.doi.org/10.2136/sssaj2011.0390

Cook, K. L. (2017). An evaluation of the effectiveness of low-cost UAVs and structure from motion for geomorphic change detection. Geomorphology, 278, 195-208. doi: http://dx.doi.org/10.1016/j.geomorph.2016.11.009

Chaplot, V. (2013). Impact of terrain attributes, parent material and soil types on gully erosion. Geomorphology, 186, 1-11. doi: http://dx.doi.org/10.1016/j.geomorph.2012.10.031

Christian, P., \& Davis, J. (2016). Hillslope gully photogeomorphology using structure-from-motion. Zeitschrift fur Geomorphologie, 60, 59-78. doi: http://dx.doi.org/10.1127/zfg_suppl/2016/00238

Ehiorobo, J. O., \& Audu, H. A. P. (2012). Monitoring of gully erosion in an urban area using geoinformation technology. Journal of Emerging Trends in Engineering and Applied Sciences, 3(2), $270-275$.

Ely, J. C., Graham, C., Barr, I. D., Rea, B. R., Spagnolo, M., \& Evans, J. (2017). Using UAV acquired photography and structure from motion techniques for studying glacier landforms: application to the glacial flutes at Isfallsglaciären. Earth Surface Processes and Landforms, 42(6), 877-888. doi: http://dx.doi.org/10.1002/esp.4044

Evans, M., \& Lindsay, J. (2010). High resolution quantification of gully erosion in upland peatlands at the landscape scale. Earth Surface Processes and Landforms, 35(8), 876-886. doi: http://dx.doi.org/10.1002/esp. 1918

Fernández, T., Pérez, J. L., Cardenal, J., Gómez, J. M., Colomo, C., \& Delgado, J. (2016). Analysis of landslide evolution affecting olive groves using UAV and photogrammetric techniques. Remote Sensing, 8(10). doi: http://dx.doi.org/10.3390/rs8100837 
Frankl, A., Stal, C., Abraha, A., Nyssen, J., Rieke-Zapp, D., De Wulf, A., \& Poesen, J. (2015). Detailed recording of gully morphology in 3D through image-based modelling. Catena, 127, 92101. doi: http://dx.doi.org/i.catena.2014.12.016

Gómez-Gutiérrez, Á., Schnabel, S., Berenguer-Sempere, F., Lavado-Contador, F., \& RubioDelgado, J. (2014). Using 3D photo-reconstruction methods to estimate gully headcut erosion. Catena, 120(0), 91-101. doi: http://dx.doi.org/10.1016/j.catena.2014.04.004

Gómez-Gutiérrez, Á., Schnabel, S., De Sanjosé, J. J., \& Contador, F. L. (2012). Exploring the relationships between gully erosion and hydrology in rangelands of SW Spain. Zeitschrift fur Geomorphologie, 56(suppl. 1), 27-44. doi: http://dx.doi.org/10.1127/0372-8854/2012/S$\underline{00071}$

Gómez Gutiérrez, Á., Schnabel, S., \& Contador, F. L. (2009). Gully erosion, land use and topographical thresholds during the last 60 years in a small rangeland catchment in SW Spain. Land Degradation and Development, 20(5), 535-550. doi: http://dx.doi.org/10.1002/ldr.931 Herguido, E., Lavado Contador, J. F., Gómez Gutiérrez, Á., \& Schnabel, S. (2017). Modeling Tree Loss Versus Tree Recruitment Processes in SW Iberian Rangelands as Influenced by Topography and Land use and Management. Land Degradation \& Development, 28(5), 1652-1664. doi: http://dx.doi.org/10.1002/ldr.2697

Hu, G., Wu, Y., Liu, B., Zhang, Y., You, Z., \& Yu, Z. (2009). The characteristics of gully erosion over rolling hilly black soil areas of Northeast China. Journal of Geographical Sciences, 19(3), 309-320. doi: http://dx.doi.org/10.1007/s11442-009-0309-4

Hugenholtz, C. H., Whitehead, K., Brown, O. W., Barchyn, T. E., Moorman, B. J., Leclair, A., Riddell, K., \& Hamilton, T. (2013). Geomorphological mapping with a small unmanned aircraft system (sUAS): Feature detection and accuracy assessment of a photogrammetrically-derived digital terrain model. Geomorphology, 194, 16-24. doi: hitp://dx.doi.org/10.1016/j.geomorph.2013.03.023

Humphrey, N. F., \& Heller, P. L. (1995). Natural oscillations in coupled geomorphic systems: an alternative origin for cyclic sedimentation. Geology, 23, 499-502. doi: http://dx.doi.org/10.1130/0091-7613(1995)023<0499:NOICGS>2.3.CO;2

James, M. R., \& Robson, S. (2012). Straightforward reconstruction of 3D surfaces and topography with a camera: Accuracy and geoscience application. Journal of Geophysical Research, 117, 1-17. doi: http://dx.doi.org/10.1029/2011JF002289

James, M. R., \& Robson, S. (2014). Mitigating systematic error in topographic models derived from UAV and ground-based image networks. Earth Surface Processes and Landforms, 39(10), 14131420. doi: http://dx.doi.org/10.1002/esp.3609 
James, M. R., Robson, S., D'oleire-Oltmanns, S., \& Niethammer, U. (2017). Optimising UAV topographic surveys processed with structure-from-motion: Ground control quality, quantity and bundle adjustment. Geomorphology, 280, 51-66. doi: http://dx.doi.org/0.1016/j.geomorph.2016.11.021

Kaiser, A., Neugirg, F., Rock, G., Müller, C., Haas, F., Ries, J., \& Schmidt, J. (2014). Small-Scale Surface Reconstruction and Volume Calculation of Soil Erosion in Complex Moroccan Gully Morphology Using Structure from Motion. Remote Sensing, 6(8), 7050. doi: http://dx.doi.org/10.3390/rs6087050

Lucieer, A., Jong, S. M., \& Turner, D. (2014). Mapping landslide displacements using Structure from Motion (SFM) and image correlation of multi-temporal UAV photography. Progress in Physical Geography, 38(1), 97-116. doi: http://dx.doi.org/10.1177/0309133313515293

Mosbrucker, A. R., Major, J. J., Spicer, K. R., \& Pitlick, J. (2017). Camera system considerations for geomorphic applications of SFM photogrammetry. Earth Surface Processes and Landforms, 42, 969-986. doi: http://dx.doi.org/10.1002/esp.4066

Neugirg, F., Stark, M., Kaiser, A., Vlacilova, M., Della Seta, M., Vergari, F.,...Haas, F. (2016). Erosion processes in calanchi in the Upper Orcia Valley, Southern Tuscany, Italy based on multitemporal high-resolution terrestrial LiDAR and UAV surveys. Geomorphology, 269, 8-22. doi: http://dx.doi.org/10.1016/j.geomorph.2016.06.027

Perroy, R. L., Bookhagen, B., Asner, G. P., \& Chadwick, O. A. (2010). Comparison of gully erosion estimates using airborne and ground-based LIDAR on Santa Cruz Island, California. Geomorphology, 118, 288-300. doi: http://dx.doi.org/10.1016/j.geomorph.2010.01.009

Poesen, J., Nachtergaele, J., Verstraeten, G., \& Valentin, C. (2003). Gully erosion and environmental change: importance and research needs. Catena, 50, 91-133. doi: http://dx.doi.org/10.1016/S0341-8162(02)00143-1

Pulido-Fernández, M., Schnabel, S., Lavado-Contador, J. F., Miralles Mellado, I., \& Ortega Pérez, R. (2013). Soil organic matter of Iberian open woodland rangelands as influenced by vegetation cover and land management. Catena, 109, 13-24. doi: http://dx.doi.org/10.1016/j.catena.2013.05.002

Ries, J. B., \& Marzolff, I. (2003). Monitoring of gully erosion in the Central Ebro Basin by largescale aerial photography taken from a remotely controlled blimp. Catena, 50(2-4), 309-328. doi: http://dx.doi.org/10.1016/S0341-8162(02)00133-9

Rubio-Delgado, J., Schnabel, S., Gómez Gutiérrez, Á., \& Berenguer-Sempere, F. (2014). Estimación de tasas de erosión históricas en dehesas utilizando raíces arbóreas expuestas y láser escáner terrestre. Cuaternario y Geomorfología, 28(3-4), 69-84. 
Schnabel, S. (1997). Soil erosion and runoff production in a small watershed under silvo-pastoral landuse (dehesas) in Extremadura, Spain. Logroño: Geoforma Ediciones.

Smith, M. W., \& Vericat, D. (2015). From experimental plots to experimental landscapes: topography, erosion and deposition in sub-humid badlands from Structure-from-Motion photogrammetry. Earth Surface Processes and Landforms, 40(12), 1656-1671. doi: http://dx.doi.org/10.1002/esp.3747

Thomas, J. T., Iverson, N. R., Burkart, M. R., \& Kramer, L. A. (2004). Long term growth of a valleybottom gully, wester lowa. Earth Surface Processes and Landforms, 29, 995-1009. doi: http://dx.doi.org/10.1002/esp. 1084

Tufekcioglu, M., Schultz, R. C., Zaimes, G. N., Isenhart, T. M., \& Tufekcioglu, A. (2013). Riparian Grazing Impacts on Streambank Erosion and Phosphorus Loss Via Surface Runoff. Journal of the American Water Resources Association, 49(1), 103-113. doi: http://dx.doi.org/10.1111/jawr.12004

Turner, D., Lucieer, A., \& De Jong, S. (2015). Time Series Analysis of Landslide Dynamics Using an Unmanned Aerial Vehicle (UAV). Remote Sensing, 7(2), 1736. doi: http://dx.doi.org/10.3390/rs70201736

Wang, R., Zhang, S., Pu, L., Yang, J., Yang, C., Chen, J.,...Sang, X. (2016). Gully erosion mapping and monitoring at multiple scales based on multi-source remote sensing data of the sancha river catchment, Northeast China. ISPRS International Journal of Geo-Information, 5(11). doi: http://dx.doi.org/10.3390/ijgi5110200

Watts, A. C., Ambrosia, V. G., \& Hinkley, E. A. (2012). Unmanned Aircraft Systems in Remote Sensing and Scientific Research: Classification and Considerations of Use. Remote Sensing 4(6), 1671. doi: http://dx.doi.org/10.3390/rs4061671

Westoby, M. J., Brasington, J., Glasser, N. F., Hambrey, M. J., \& Reynolds, J. M. (2012). 'Structure-from-Motion' photogrammetry: A low-cost, effective tool for geoscience applications. Geomorphology, 179(0), 300-314. doi: http://dx.doi.org/10.1016/j.geomorph.2012.08.021

Westoby, M. J., Dunning, S. A., Woodward, J., Hein, A. S., Marrero, S. M., Winter, K., \& Sugden, D. E. (2016). Interannual surface evolution of an Antarctic blue-ice moraine using multitemporal DEMs. Earth Surface Dynamics, 4(2), 515-529. doi: http://dx.doi.org/10.5194/esurf4-515-2016

Zaimes, G. N., \& Schultz, R. C. (2012). Assessing Riparian Conservation Land Management Practice Impacts on Gully Erosion in lowa. Environmental Management 49(5), 1009-1021. doi: http://dx.doi.org/10.1007/s00267-012-9830-9 
Zucca, C., Canu, A., \& Della Peruta, R. (2006). Effects of land use and landscape on spatial distribution and morphological features of gullies in an agropastoral area in Sardinia (Italy). Catena 68(2-3), 87-95. doi: http://dx.doi.org/10.1016/j.catena.2006.03.015 